\title{
BIODIVERSITY AND OCCURRENCE OF ENTOMOP ATHOGENIC AGENTS IN SUEZ CANAL AREA- EGYPT
}

\author{
SAYED, ATEF M.M. ${ }^{1}$; S. A. A. EBRAHIM²; A. M. M. ELADAWY'
}

1- Plant Protection Research Institute, ARC., Giza, Egypt.

2- Department of Plant Production, Faculty of Environmental Agricultural Sciences, Arish University.

Corresponding: Atef Mahmoud Mohamed Sayed, 4.5 Eiz-Eldeen Street, 41511, Ismailia Agricultural Research Station, Plant Protection Department, Ismailia, P.O. 321. Egypt. Email: atef.mahmoud1@gmail.com.

(Manuscript received 20 September 2017)

\begin{abstract}
$\mathrm{O}$ ccurrence and distribution of entomopathogenic agents were studied in soil samples collected from three districts at Suez Canal area, Egypt. Entomopathogens were isolated by the bait method using larvae of Mediterranean flour moth, Anagasta kuehniella Zeller. Twenty-six fungal genera infected, three bacterial species and one species of nematode were identified using morphological characteristics and molecular technique. Distribution and occurrence were significantly varied among the three studied districts and biological agents. The occurrence of the entomopathogens in the collected soil samples were $49.11,24.56$, and $4.63 \%$ found out in $138.0,69.0$ and 13.0 of the total soil samples (281) in the three surveyed districts of Ismailia, Suez and Portsaid, respectively. Therefore, the highest frequency was occurred in Ismailia at $62.23 \%$, followed by Suez district $31.36 \%$. The lowest frequency has occurred in Portsaid district at $5.91 \%$. On the other hand, the entomopathogenic fungi were the most abundant of the studied entomopathogenic agents, in the three districts representing $40.21,16.73$, and $3.56 \%$ in Ismailia, Suez and Portsaid, respectively. The existed bacteria in the surveyed districts were representing $6.76,6.76$ and $1.07 \%$ in Ismailia, Suez and Portsaid, respectively, whereas, the entomopathogenic nematode was the lowest, representing 2.14 and $1.07 \%$ in Ismailia and Suez districts, respectively. The pathogenicity of the obtained agents was estimated using Koch's postulates. The mortality rates of $A$. kuehniella larvae were found to range from 12.67 to $86.00 \%$. Isolated fungi, Beauveria bassiana, Metarhizium anisopliae, Paecilomyces fumosoroseus and Lecanicillium lecanii were the most virulent bioagents. Biodiversity indices results revealed that the variance among the three districts were significant differences in all diversity indices (richness, evenness, Shannon and Simposen indices). The community of entomopathogenic species recorded in Ismailia district was significantly more diverse of pathogen communities than recorded in Suez and Portsaid. The gained results clarify that soil physiochemical properties affect the level of occurrence of the microbial agents in quantitatively.
\end{abstract}

Keywords: Entomopathogenic agents, Occurrence and frequency, Biodiversity, edaphic factors 


\section{INTRODUCTION}

Insect pest control has relied mostly on chemical insecticides which have generated several problems including insecticides resistance, outbreaks of secondary pests normally held in check by natural enemies, safety risks for humans and domestic animals, contamination of ground water, a decrease in biodiversity, and other environmental concerns, besides the high cost of chemical control application. These problems and sustainability of programs based predominantly on chemicals have provided an impetus for exploring the change in control tactics to find economically and environmentally sound alternatives for pest control (Glare et al., 2016).

Biological control offers an attractive alternative or supplement to the use of chemical pesticides. Insect pathogens or microbial control such as using of fungi, bacteria, virus, protozoa and nematodes show great promising agents as potential biological control agents (Ravensberg, 2011).

The establishment of microbial control system requires a survey of the biocontrol agent existing naturally in the agriculture soils. Survey of insect pathogens is an important and widespread component of most terrestrial ecosystems and plays a key role in regulating pest populations and epizootic development (Vega et al., 2009). The isolation and characterization of native entomopathogens are essential to provide an insight into naturally occurring pathogens biodiversity of a specific region and to provide a pool of potential biological control agents to be conserved (Quesada-Moraga et al., 2007). The presence of several entomopathogen species can be considered as an indicator of their ability to survive in that environment (Meyling \& Eilenberg, 2007). The soil is the natural habitat for a large diversity of microorganisms. Discovering new strains and knowledge of fundamental aspects of the ecology of the entomopathogens are necessary. To understand more about the insect-pathogen dynamics in the soil, studies on the natural occurrence and distribution of insect pathogens in different soil types and in different geographical regions are necessary. Ecological studies on the occurrence of all insect-associated pathogens in the soil are needed too.

The present study aimed to I: study the occurrence, distribution and diversity of native strains of entomopathogenic agents in different soil types; II: Estimate the pathogenicity of the obtained entomopathogenic agents. III: Investigate diversity indices for the obtained bioagents at the three studied districts, and IV: Determine the effect of some edaphic factors on the distribution of the obtained bioagents. 


\section{MATERIALS AND METHODS}

\subsection{Study area}

The present work was carried out at Ismailia, Suez and Portsaid of the Suez Canal Zone districts, located in the northeastern part of Egypt. The coordinate (Longitude: Latitude) areas lie, as shown in Table 1. The previous three districts were including 4 locations of Ismailia, Abu-sweir, Al-Kasassin, and Quantara- Gharb in Ismailia district; 4 locations of Amer, Alshalofa, Kabreet, and Genifa in Suez district; and only one location in Portsaid district as shown in Table 1.

Table 1. Districts, locations, number of collected samples and coordinated of the investigated soils.

\begin{tabular}{|c|c|c|c|c|}
\hline Governorate & Location & No. soil samples & \multicolumn{2}{|c|}{ Coordinates } \\
\hline \multirow{4}{*}{$\begin{array}{l}\text { Ismailia } \\
\text { (4 locations) }\end{array}$} & Ismailia & 40 & $30^{\circ} 34^{\prime} 59.13 " \mathrm{~N}$ & $32^{\circ} 15^{\prime} 55.4^{\prime \prime} \mathrm{E}$ \\
\hline & Abu-sweir & 40 & $30^{\circ} 33^{\prime} 52.20^{\prime \prime} \mathrm{N}$ & $31^{\circ} 64^{\prime} 25.0 " \mathrm{E}$ \\
\hline & Al-kasassin & 40 & $30^{\circ} 33^{\prime} 49.31 " \mathrm{~N}$ & $31^{\circ} 56^{\prime} 0.80^{\prime \prime} \mathrm{E}$ \\
\hline & Quantara-Gharb & 40 & $30^{\circ} 49^{\prime} 40.99 " \mathrm{~N}$ & $32^{\circ} 11^{\prime} 50.3^{\prime \prime} \mathrm{E}$ \\
\hline \multirow{4}{*}{$\begin{array}{l}\text { Suez } \\
\text { (4 locations) }\end{array}$} & Amer & 20 & $30^{\circ} 1.0^{\prime} 8.20^{\prime \prime} \mathrm{N}$ & $32^{\circ} 33^{\prime} 27.7^{\prime \prime} \mathrm{E}$ \\
\hline & Al-shalofa & 20 & $30^{\circ} 6.0^{\prime} 3.00^{\prime \prime} \mathrm{N}$ & $32^{\circ} 33^{\prime} 38.0^{\prime \prime} \mathrm{E}$ \\
\hline & Kabreet & 30 & $30^{\circ} 13^{\prime} 45.00^{\prime \prime N}$ & $32^{\circ} 28^{\prime} 7.50^{\prime \prime} \mathrm{E}$ \\
\hline & Genifa & 30 & $30^{\circ} 13^{\prime} 27.00^{\prime \prime} \mathrm{N}$ & $32^{\circ} 24^{\prime} 46.4^{\prime \prime} \mathrm{E}$ \\
\hline $\begin{array}{l}\text { Portsaid } \\
\text { (1 location) }\end{array}$ & Portsaid & 21 & \multicolumn{2}{|l|}{$3052^{\prime} 38.40 " \mathrm{~N}$} \\
\hline
\end{tabular}

\subsection{Soil sampling and preparation}

Soil samples were collected approximately from each of 100 feddan / location. The longitude and latitude of each soil sample were identified with coded numbers, using global positioning system (GPS) equipment (Garmin, etrex, Garmin Ltd) that used to view, edit, plot data and export data to geographical information system (GIS), that generate base maps of the research area. Maps were developed by the assistance of a GIS consultant. These initial maps were useful in visually planning for this investigation.

Two hundred and eighty one of soil samples were collected over two seasons throughout August 2014 to February 2016 from 9 locations covering the main regions of the Suez Canal Zone districts (Table 1).

At each location, soil samples about (1 $\mathrm{kg}$ each) were collected from a depth of $0-10 \mathrm{~cm}$ of the soil surface layer using the sterilized auger and sieved using a 2-mm pore sieve to remove large clumps and stones. The sieved soil was placed in plastic bag. Each sample was divided to two subsamples, one for isolation and identification 
and the other for analysis of soil properties. Collected samples were stored at $4^{\circ} \mathrm{C}$ until starting isolation process (no more than two weeks). Each sample was subjected to examination and analysis at each of the Plant Protection, Plant pathology and Soil Testing laboratories of Ismailia Agricultural Research station, Ismailia, Egypt.

\subsection{Isolation of entomopathogen species.}

\subsubsection{Maintaining insect larvae of Mediterranean flour moth, Anagasta kuehniella Zeller}

For establishing a colony of Mediterranean flour moth, the following technique as described by EL-Adawy et al., 2012 was done. Briefly, the strain of the insect was received to the laboratory in Plant Protection Department, Faculty of Agriculture, Suez Canal University- Ismailia, Egypt. The colony was established in the laboratory of plant protection at Ismailia Agricultural Research Station.

The culture was reared on sterilized wheat flour, wheat bran with $5 \%$ yeast powder, and then placed in glass pots $(500 \mathrm{~mL})$ up to $3 / 4$ depth. The pots were covered with fastened cheese cloth. The colony was kept in cheese cloth cage $60 \times$ $60 \times 60 \mathrm{~cm}$ away from any contamination under constant temperature at $25 \pm 2^{\circ} \mathrm{C}$ and relative humidity of $65 \pm 5 \%$. Each week, $1 / 4$ of the infested brain was transferred to new clean glass pots $(500 \mathrm{~mL})$ has uninfected brain up to $3 / 4$ depth. In order to have sufficient numbers of individual available, two containers were prepared simultaneously weekly. After 8 weeks of cultivation, this gives enough neonate numbers for testing.

\subsubsection{Soil baiting technique:}

\subsubsection{Fungal and bacterial isolations}

The soil baiting method was used in this study adapted from EL-Adawy et al., 2012. Briefly, each soil sample was homogenized using a metal sieve with pore size 4 $\mathrm{mm}$. One hundred grams of sieved soil were placed in transparent plastic cup $200 \mathrm{~mL}$ leaving $1 \mathrm{~cm}$ of airspace at the top, then re-moistened with sterile distilled water so that it was "slightly damp". Ten healthy $2^{\text {nd }}$ larval instar of $A$. kuehniella from a laboratory stock rearing added to each cup. A lid with ventilation holes was placed on top of each sample and the cups were stacked upside down to induce the movement of the larvae through the soil.

Soil samples were moistened with sterile distilled water using a manual plastic sprayer whenever deemed necessary. The cups were stored in climatic conditions at $25 \pm 1^{\circ} \mathrm{C}$ and $70 \pm 5 \%$ relative humidity in darkens. Every $1-2$ days the cups were rotated so that the orientation of the cups shifted, forcing the $A$. kuehniella larvae to move through the soil substrate increasing the likelihood they would come in contact with entomopathogens in the soil. 
Inspection of dead and survived insects was checked every three days for a period of four weeks. Dead larvae were removed and surface sterilized by immersion in sodium hypochlorite $2 \%$ for $30 \mathrm{~s}$ to prevent the growth of the contaminated saprophytic microbes. The cadavers were washed three times with sterile distilled water and individually placed in a Petri dish that provided with a moist piece of sterilized filter paper. Using a sterile inoculation needle, fungal and bacterial isolations were made from insect cadavers and plated on media of PDA ( $4.0 \mathrm{~g}$ potato extract, mix with Dextrose $20 \mathrm{gm}$, Agar $15 \mathrm{gm}$ and $1 \mathrm{~L}$ distilled water) and Luria Bertani (LB) (10 $\mathrm{g}$ tryptone peptone, $5 \mathrm{~g}$ yeast extract, $5 \mathrm{~g}$ sodium chloride, $15 \mathrm{~g}$ Bacto agar (Difco), 1 L distilled water), respectively. After 1-2 weeks growth colonies were evaluated, morphologically identified and isolates were kept for further studies.

\subsubsection{The entomopathogenic nematode isolation}

The modified technique as described by Kaya \& Gaugler, 1993 was followed for isolation the infective juveniles from the dead Mediterranean flour larvae, suspected to be infected with entomopathogenic nematodes.

\subsection{Identification}

The fungal culture was morphologically identified with the aid of relevant taxonomic key (Promputtha et al., 2005). Bergeys' manual of systematic bacteriology (Logan \& De Vos, 2009) was used for identified bacterial cultures. Key of Kaya \& Stock (1997) was used to identify the unknown species of nematodes. The biomass obtained of fungal and bacterial isolates were re-isolated and purified in sub-culture on PDA and LB plates, respectively for DNA extraction. The fungal and bacterial isolates were identified by PCR amplification and sequencing. DNA sequencing was performed and analyzed to determine the genus with the highest similarity to the insect pathogenic isolates in Crop Bioprotection Research Unit, National Center for Agricultural Research, Agricultural Research Service, United States Department of Agriculture - USA.

\subsection{Pathogenicity test (Koch's postulates)}

The pathogenicity of the obtained pathogens was bio-assayed on the $2^{\text {nd }}$ larval instar of $A$. kuehniella. The tested pathogens were grown on PDA plate for 1012 days. The spores were washed with $1 \mathrm{~mL}$ sterile water. Each spore suspension was collected into $1.5 \mathrm{~mL}$ tube. A. kuehniella larvae were immersed into the spore suspension with forceps for about 3-5 $\mathrm{s}$, and then transferred into $9 \mathrm{~cm}$ diameter Petri dishes with moistened filter paper. Petri dishes were sealed with parafilm to maintain the humidity, and were incubated at the temperature of $20-25^{\circ} \mathrm{C}$ in darkness. Infected larvae were inspected daily until dead. 
The fungal structures growing out of the dead larvae were identified morphologically based on its morphological characteristic to evaluate the cause of death. Nematodes were tested using the technique of Woodring \& Kaya (1988). Ten larvae were treated for insect pathogens and the experiment was carried out three times to evaluate the pathogenicity of the entomopathogens. The mortality percentages were calculated.

In each entomopathogen species were considered to be three replications, each of 10 larvae per Petri-dish as a replication for laboratory bioassay. The numbers of live and dead larvae were counted to calculate the mortality percentage for each species. Dead larvae that were not symptomatic for both microbe infections were omitted from statistical analysis. No-microbe controls were included with each assay to indicate handling mortality of the larvae, which typically averaged less than $2 \%$ and data were not corrected for control mortality. The data for insect larval mortality were assessed by analysis of variance. Means were separated using the least significant difference (LSD) test at significant level 0.05 .

\subsection{Diversity index}

Four derived biodiversity indices, richness, Shannon's diversity index, Simpson's diversity index, and evenness (J) (Pielou's Index) were used (Magurran, 2004), for statistical analyses in this study as following formula:

$$
\begin{aligned}
& \text { Richness (S) } \\
& \mathrm{S}=\text { number of species in the community } \\
& \text { Simpson's diversity Index (D) } \\
& \mathrm{D}=\frac{\sum \mathrm{n}_{i}\left(\mathrm{n}_{i}-1\right)}{\mathrm{N}(\mathrm{N}-1)} \\
& \text { Shannon 's-Weaver diversity Index }(H) \\
& I=-\sum_{j=1}^{N} p_{s} \ln p_{s} \\
& \text { Evenness (J) (Pielou's Index) } \\
& E_{S}=H / h_{\max }=H / \ln S \\
& \text { Where: } \\
& \mathrm{Pi}=\text { Relative abundance of the species. } \\
& \mathrm{N}=\text { Total number of isolates for all kinds. } \\
& \mathrm{n}=\text { number of species. } \\
& \mathrm{Ln}=\log \text { to base }
\end{aligned}
$$

\subsection{Physical and chemical properties of soils}

To determine the relationship between occurrence of the entomopathogenic agents and each of chemical and physical properties of the soil, $250 \mathrm{gm}$ for each soil samples were subjected to chemical and physical properties using the methods adopted by Jackson (1967) and Gee \& Bauder (1986).

The collected soil samples were air-dried, crushed with wooden ground machine, passed through a $2 \mathrm{~mm}$ stainless steel sieve and kept in polyethylene bags 
for different analysis. Particle size distribution was carried out by the pipette method using sodium hexamite-phosphate as a dispersing agent. Each soil sample was diluted to make suspension extract constituents at ratio of 1:5. Carbonates, bicarbonates, chlorides, sulphates, calcium, magnesium, sodium, potassium, organic matter and total soluble salts in soil samples were estimated.

\subsection{Data analysis}

Standard methods for $x^{2}$ were used for comparison of occurrence of insect pathogens in soil sampled from three districts. All analysis was performed using QLMicro 2016 Excel - Stat software for statistical data processing.

\section{Result}

\subsection{Occurrence and frequency rates}

Data in Table 2 elucidated the total number of isolates, percentages of the occurrence and frequency of the monitored microbial species in the three surveyed districts. The insect -associated pathogens in Ismailia district were found in 138 soil samples out of the total 160 represented $86.25 \%$. The entomopathogens were including to 26 fungi, 3 of bacteria and only one species of nematode. Entomopathogenic fungi were the most abundant showing $70.63 \%$ (113 out of 160 ), followed by bacteria $11.88 \%$, whereas, nematodes $3.75 \%$. Otherwise, the insect pathogenic fungi were the most frequently as $81.88 \%$, followed by the bacterium species $13.77 \%$, while the nematodes were the least $4.35 \%$.

In Suez district, the entomopathogenic agents were found in 69 samples out of 100 the total soil samples, represented $69 \%$. It was 14 fungi, 2 of bacteria and only one species of nematode. Entomopathogenic fungi was the most abundant, the occurrence represented $47.00 \%$, followed by bacteria species $19.00 \%$; whereas, nematode representing $3.00 \%$. However, the entomopathogenic fungi species were found the most frequently as $81.90 \%$, followed by the bacterium species $27.54 \%$; while the nematodes were less frequent as $4.35 \%$.

On other hand, the entomopathogens agents were found in 13 samples out of the total soil samples 21 represented $61.90 \%$ of the insect-associated pathogens in Portsaid district. The entomopathogens were belonging to 8 fungi and 2 species of bacteria. Insect-pathogenic fungi were the more the abundant, representing $47.62 \%$ than bacteria $14.29 \%$. However, the insect pathogenic fungi species were found the most frequently as $76.92 \%$, followed by the bacterium species were found frequently $23.08 \%$ in the isolates. 
Table 2. Total numbers of isolates, occurrence and frequency of isolated pathogens from soils of Ismailia, Suez and Portsaid districts.

\begin{tabular}{|l|c|c|c|c|c|}
\hline District & $\begin{array}{c}\text { Isolated } \\
\text { microbial } \\
\text { agents }\end{array}$ & $\begin{array}{c}\text { No. of } \\
\text { species }\end{array}$ & $\begin{array}{c}\text { No. of } \\
\text { isolates }\end{array}$ & Occurrence \% ${ }^{\mathrm{a}}$ & Frequency \% ${ }^{\mathrm{b}}$ \\
\hline \multirow{4}{*}{$\begin{array}{l}\text { Ismailia } \\
\left(\mathrm{n}^{*}=160\right)\end{array}$} & Fungi & 26.00 & 113.00 & 70.63 & 81.88 \\
\cline { 2 - 6 } & Bacteria & 3.00 & 19.00 & 11.88 & 13.77 \\
\cline { 2 - 6 } & Nematodes & 1.00 & 6.00 & 3.75 & 4.348 \\
\cline { 2 - 6 } & Total & 30.00 & 138.0 & 86.26 & 100.00 \\
\hline \multirow{4}{*}{$\left.\begin{array}{l}\text { Suez } \\
n\end{array}=100\right)$} & Fungi & 14.00 & 47.00 & 47.00 & 68.12 \\
\cline { 2 - 6 } & Bacteria & 2.00 & 19.00 & 19.00 & 27.54 \\
\cline { 2 - 6 } & Nematodes & 1.00 & 3.00 & 3.00 & 4.34 \\
\cline { 2 - 6 } & Total & 17.00 & 69.00 & 69.00 & 700.00 \\
\hline \multirow{2}{*}{$\begin{array}{l}\text { Portsaid } \\
(n=21)\end{array}$} & Fungi & 8.00 & 10.00 & 47.62 & 23.08 \\
\cline { 2 - 6 } & Bacteria & 2.00 & 3.00 & 14.29 & 0.00 \\
\cline { 2 - 6 } & Nematodes & 0.00 & 0.00 & 0.00 & 100.00 \\
\cline { 2 - 6 } & Total & 10.00 & 13.00 & 61.90 & \\
\hline
\end{tabular}

$a=$ Occurrence \%: number of soil sample which contain a specific entomopathogenic

species /total number of collected soil sample of the same site.

$\mathrm{b}=$ Frequency of occurrence $(\mathrm{F}) \%=$ number of isolates of a specific pathogens /total number of all isolates. $\mathrm{n}=$ Total number of collected sample of soils in each district.

It obvious that in Table 3, the entomopathogenic fungi were the most abundant of the microbial agents distributed and found in all districts representing 40.21, 16.73, and 3.56\% in Ismailia, Suez and Portsaid, respectively.

Bacteria species existed in the surveyed districts representing 6.76, 6.76 and $1.07 \%$ in Ismailia, Suez and Portsaid, respectively; whereas, entomopathogenic nematode was the lowest abundant representing 2.14 and $1.07 \%$ in Ismailia and Suez districts, respectively. Also, the highest frequency of the microbial agent was the entomopathogenic fungi representing 51.36, 21.36 and 4.55\% in Ismailia, Suez and Portsaid, respectively. However, bacteria species existed in the surveyed districts representing $8.64,8.64$ and $1.36 \%$ in Ismailia, Suez and Portsaid, respectively, whereas, entomopathogenic nematodes existed was the lowest frequency percentage representing 2.72 and $1.36 \%$ in Ismailia and Suez districts, respectively (Table 3). 
Table 3. Total number of isolates, occurrence and frequency of isolated pathogens from soils of Ismailia, Suez and Portsaid districts.

\begin{tabular}{|c|c|c|c|c|c|c|c|c|c|c|c|c|}
\hline \multirow{3}{*}{$\begin{array}{l}\text { Isolated } \\
\text { microbial } \\
\text { agents } \\
\left(n^{*}=281\right)\end{array}$} & \multicolumn{4}{|c|}{ Total no. of isolates } & \multicolumn{4}{|c|}{ Occurrence \% a } & \multicolumn{4}{|c|}{ Frequency $\%{ }^{b}$} \\
\hline & \multicolumn{4}{|c|}{ Districts } & \multicolumn{4}{|c|}{ Districts } & \multicolumn{4}{|c|}{ Districts } \\
\hline & Ismailia & Suez & Portsaid & Total & Ismailia & Suez & Portsaid & Total & Ismailia & Suez & Portsaid & Total \\
\hline Fungi & 113.00 & 47.00 & 10.00 & 170.00 & 40.21 & 16.73 & 3.56 & 60.50 & 51.36 & 21.36 & 4.55 & 77.27 \\
\hline Bacteria & 19.00 & 9.00 & 3.00 & 41.00 & 6.76 & 6.76 & 1.07 & 14.59 & 8.64 & 8.64 & 1.36 & 18.64 \\
\hline ematodes & 6.00 & 3.00 & 0.00 & 9.00 & 2.14 & 1.07 & 0.00 & 3.21 & 2.72 & 1.36 & 0.00 & 4.09 \\
\hline Total & 138.00 & 9.00 & 13.00 & 220.00 & 49.11 & 24.57 & 4.63 & 78.30 & 62.73 & 31.36 & 5.91 & 100.00 \\
\hline
\end{tabular}

$\mathrm{a}=$ Occurrence \%: number of soil sample which contain a specific entomopathogenic species /total number of collected soil sample of the same site.

$b=$ Frequency of occurrence $(F) \%=$ number of isolates of a specific /total number of all isolates.

$\mathrm{n}=$ Total number of collected sample of soils in all districts

Statistical analysis of the occurrence, the obtained entomopathogens revealed high significantly different among the three surveyed districts and the recorded pathogens $\left(X^{2}=65.197, d f=24, p<0.0001\right)$. The greatest occurrence was found in Ismailia district (49.11\%), followed by Suez district (24.56\%), whereas the lowest was found at Portsaid district (4.63\%). Therefore, the entomopathogenic species were found the greatest frequently as $62.73 \%$, in Ismailia district, followed by Suez district were found frequently $31.36 \%$, while in Portsaid were the least frequent as $5.91 \%$ (Table 3).

\subsection{Pathogenicity of the isolated pathogens}

Results of using Koch's postulates showed the mortality rates of the infected A. kuehniella larvae by isolated pathogen from the three districts Ismailia, Suez and Portsaid districts in Table 4.

\subsubsection{Ismailia District}

The obtained pathogens caused mortality ranged from $19.67 \%$ to $86.00 \%$ to larvae of Mediterranean flour moth. Isolated fungi Beauveria bassiana, Paecilomyces fumosoroseus, and Metarhizium anisopliae were the most virulent compared to other pathogens, it recorded 73.30, 66.60, and $60.00 \%$ mortality percentages, respectively (Table 4). The isolated fungus Aspergillus niger was the lowest virulence percentage as11.00\%. While, isolated bacteria, Bacillus megaterium and nematodes Heterorhabditis $s p$. showed mortality rates of up to 57.00 and $43.33 \%$, respectively. 
Table 4. Pathogenicity of the isolated entomopathogens from Ismailia, Suez and Portsaid districts.

\begin{tabular}{|c|c|c|c|c|c|c|}
\hline \multirow[t]{2}{*}{ No. } & \multicolumn{2}{|c|}{ Ismailia } & \multicolumn{2}{|l|}{ Suez } & \multicolumn{2}{|c|}{ Portsaid } \\
\hline & $\begin{array}{c}\text { Isolated } \\
\text { microorganisms }\end{array}$ & $\begin{array}{c}\text { Mortalit } \\
y\end{array}$ & $\begin{array}{c}\text { Isolated } \\
\text { microorganisms }\end{array}$ & $\begin{array}{l}\text { Mortalit } \\
\text { y (mean }\end{array}$ & $\begin{array}{c}\text { Isolated } \\
\text { microorganisms }\end{array}$ & $\begin{array}{l}\text { Mortality } \\
\text { (mean } \pm\end{array}$ \\
\hline 1 & Alternaria sp. & $26.62 \pm$ & Alternaria sp. & $39.33 \pm$ & Alternaria sp. & $37.17 \pm$ \\
\hline 2 & Aspergillus & $21.00 \pm$ & Aspergillus flavus & $35.33 \pm$ & Aspergillus flavus & $40.17 \pm$ \\
\hline 3 & Aspergillus & $31.65 \pm$ & Aspergillus niger & $12.70 \pm$ & Aspergillus niger & $19.67 \pm$ \\
\hline 4 & Aspergillus & $11.00 \pm$ & Beauveria bassiana & $65.68 \pm$ & Beauveria & $86.00 \pm$ \\
\hline 5 & Aspergillus & $36.65 \pm$ & Cladosporium & $60.33 \pm$ & Fusarium sp. & $53.17 \pm$ \\
\hline 6 & Aspergillus & $30.00 \pm$ & Fusarium sp. & $21.25 \pm$ & Lecanicilium & $53.67 \pm$ \\
\hline 7 & Beauveria & $73.30 \pm$ & Fusarium & $14.00 \pm$ & Metarhizium & $57.00 \pm$ \\
\hline 8 & Cordyceps sp. & $43.62 \pm$ & Fusarium solani & $33.75 \pm$ & Penicillium sp. & $31.67 \pm$ \\
\hline 9 & Fusarium sp. & $45.00 \pm$ & Lecanicilium lecanii & $77.00 \pm$ & Bacillus & $55.17 \pm$ \\
\hline 1 & Fusarium & $30.75 \pm$ & Metarhizium & $79.67 \pm$ & Serratia odorifea & $33.17 \pm$ \\
\hline $\begin{array}{l}1 \\
1\end{array}$ & $\begin{array}{l}\text { Fusarium } \\
\text { begonia }\end{array}$ & $\begin{array}{l}20.00 \pm \\
6.21\end{array}$ & $\begin{array}{l}\text { Paecilommyces } \\
\text { Fumosoroseus }\end{array}$ & $\begin{array}{l}61.00 \pm \\
3.61\end{array}$ & & \\
\hline 1 & Fusarium & $23.33 \pm$ & Penicillium sp. & $33.00 \pm$ & & \\
\hline 1 & Fusarium & $43.30 \pm$ & Stamphylium sp. & $24.00 \pm$ & & \\
\hline 1 & Fusarium & $43.30 \pm$ & Trichoderma sp. & $45.00 \pm$ & & \\
\hline 1 & Fusarium & $35.00 \pm$ & Bacillus & $46.75 \pm$ & & \\
\hline 1 & Fusarium & $40.00 \pm$ & Serratia odorifea & $35.00 \pm$ & & \\
\hline 1 & Fusarium & $45.00 \pm$ & Heterorhabditis sp. & $30.45 \pm$ & & \\
\hline 1 & Fusarium & $43.30 \pm$ & & & & \\
\hline 1 & Fusarium solani & $47.63 \pm$ & & & & \\
\hline 2 & Helminthosporiu & 23.32 & & & & \\
\hline 2 & Lecanicilium & $51.00 \pm$ & & & & \\
\hline 2 & Metarhizium & $60.00 \pm$ & & & & \\
\hline $\begin{array}{l}2 \\
3\end{array}$ & $\begin{array}{l}\text { Paecilomyces } \\
\text { Fumosoroseus }\end{array}$ & $\begin{array}{l}66.60 \pm \\
6.05\end{array}$ & & & & \\
\hline 2 & Penicillium sp. & $45.00 \pm$ & & & & \\
\hline 2 & Scytalidium sp. & $23.32 \pm$ & & & & \\
\hline 2 & Trichoderma sp. & $38.37 \pm$ & & & & \\
\hline 2 & Bacilus & $50.65 \pm$ & & & & \\
\hline 2 & Bacillus & $57.00 \pm$ & & & & \\
\hline 2 & Serratia odorifea & $45.00 \pm$ & & & & \\
\hline 3 & Heterorhabditis & $43.33 \pm$ & & & & \\
\hline \multicolumn{2}{|c|}{$\begin{array}{l}\text { Least Significant } \\
\text { Difference (LSD) at }\end{array}$} & 5.38 & & 6.94 & & 1.02 \\
\hline
\end{tabular}




\subsubsection{Suez District}

Results in Table 4 revealed that mortality rates caused by the pathogen isolates to Mediterranean flour moth larvae ranged from $12.70 \%$ to $79.67 \%$. Isolated fungi Metarhizium anisopliae, Lecanicillium lecanii, Beauveria bassiana were the most virulent compared to others, it recorded 79.67, 77.00, and $65.68 \%$ mortality percentages, respectively (Table 4). Isolated bacteria, Bacillus megaterium and nematode, Heterorabditis sp., that showed mortality rate of up to 46.75 and $30.45 \%$, respectively.

\subsubsection{Portsaid District}

The obtained pathogens caused the mortality ranged from $19.67 \%$ to $86.00 \%$ to Mediterranean flour moth. The mortality percentages by isolated fungi of Beauveria bassiana and Metarhizium anisopliae were the most virulent isolates compared to other pathogens, as $86.00 \%$ and $57.00 \%$, respectively. Isolated bacteria, Bacillus megaterium showed a mortality rate of up to $55.17 \%$ (Table 4). It obvious that the mortality rates were highly significant in the Ismailia district $(F=7.772$, $d f=(29,119), P>0.0001)$, Suez $(F=18.187, d f=(16,67), P>0.0001)$ and Portsaid $(F=121.45, d f=(9,39), p>0.0001)$ as shown in Table 4.

\subsection{Diversity indices}

The obtained insect-associated pathogens from the soil samples at the same district can be considered as a pathogen community. To elucidate the major variation patterns, parameters of the pathogens community of the three studied districts including; species richness, species diversity indices, and evenness were calculated as shown in Table 5.

Specie Richness (S) was a measure of the number of different kinds of organisms present in a particular area. The obtained data revealed that the maximum species diversity in the three districts was significantly varied from district to another, as 30 species in Ismailia district greater than founded in Suez (17 species) and Portsaid (10 species), ( $F=66.21, d f=(2,8), P<0.0001)$. However, diversity depends not only on richness, but also on evenness.

Simpson's Diversity Index (1-D) is a diversity index measures the probability of two individuals selected randomly from a sample belong to the same species. There was significant differences among the districts $(F=175.21, d f=(2,8), P<0.0001)$. The calculated values of this index was 0.96 in Portsaid followed by in Suez district as 0.93 , while in Ismailia district was the lowest as 0.32 . 
Table 5. Diversity indices in the three districts of Suez Canal Area.

\begin{tabular}{|l|c|c|c|}
\hline \multirow{2}{*}{ Index } & \multicolumn{2}{c|}{ Districts \pm standard errors (SE) * } \\
\cline { 2 - 4 } & Ismailia & Suez & Portsaid \\
\hline Total no. of isolates (N) & 138.00 & 69.00 & 13.00 \\
\hline Species Richness (S), (Total no. of species) & $30.00 \mathrm{a}$ & $17.00 \mathrm{~b}$ & $10.00 \mathrm{~b}$ \\
\hline Ln Richness (Ln S) & 3.40 & 2.83 & 2.30 \\
\hline Simpson's Diversity Index (1-D) & $0.32 \pm 0.04 \mathrm{c}$ & $0.93 \pm 0.51 \mathrm{~b}$ & $0.96 \pm 0.03 \mathrm{a}$ \\
\hline Shannon-Wienner 's Diversity Index (H) & $3.31 \pm 0.02 \mathrm{a}$ & $2.66 \pm 0.18 \mathrm{a}$ & $2.25 \pm 0.03 \mathrm{a}$ \\
\hline Species Evenness (J) (Pielou's Index) (H/LnS) $=\mathrm{J}$ & $0.97 \pm 0.03 \mathrm{a}$ & $0.94 \pm 0.29 \mathrm{a}$ & $0.98 \pm 0.01 \mathrm{a}$ \\
\hline
\end{tabular}

*Means $( \pm \mathrm{SE})$ followed by the different letters within row are significantly different (Tukey test, $\mathrm{P}<.05)$.

Shannon-Wienner 's Diversity index $(\mathrm{H})$ is an index applied to biological systems derived from a mathematical formula used in the communication area. It's the most preferred index among the other diversity index. However, the Shannon index compares samples of different sizes to assess number and abundance of species present. The Shannon index is essentially a measure of randomness and was not a significant difference among the districts $(F=2.79, d f=(2,8), P=0.139)$. This index value in Ismailia district (3.31) was higher than in both Suez (2.66) and Portsaid (2.25).

Evenness (J) (Pielou's index) is a measure of the relative abundance of different species making up the richness of an area. The values of evenness index (J) was not significant variance $(\mathrm{F}=5.57, \mathrm{df}=(2,8), \mathrm{P}=0.079)$ among districts, it calculated as $0.97,0.94$ and 0.98 at Ismailia, Suez and Portsaid districts, respectively.

\subsection{Chemical and Physical properties of soils}

\subsubsection{Chemical Properties}

Data in Table 6 indicate that the electrical conductivity in all soil samples ranged from 0.20 to $5.43 \mathrm{mhos} / \mathrm{cm}$; i.e. from 6.17 to 173.68 as a total soluble solid (TSS). The electrical conductivity with calculating the salinity level was the highest level in Suez district, whereas in Ismailia district was the lowest rates of salinity significant differences $\left(F_{2,11}=18.96, T=2.61, P<0.0001\right)$. Furthermore, the percentage of calcium carbonate $\left(\mathrm{CaCO}_{3}\right)$ was varied among Suez $\left(21.18 \mathrm{mg} \mathrm{L}^{-1}\right)$, Portsaid (11.2 $\left.\mathrm{mg} \mathrm{L}^{-1}\right)$ and Ismailia $\left(0.41 \mathrm{mg} \mathrm{L}^{-1}\right)$ significantly differences $\left(F_{2,11}=7.05, T=12.25\right.$, $P<0.000)$. 
Table 6. Chemical analysis of the studied soil samples in three districts of Suez Canal Area.

\begin{tabular}{|c|c|c|c|c|c|c|c|c|c|c|c|c|c|c|c|c|c|c|c|}
\hline \multirow[t]{2}{*}{ District } & \multirow[t]{2}{*}{$\mathrm{pH}$} & \multirow[t]{2}{*}{$\begin{array}{c}\mathrm{EC} \\
\mathrm{mhos} / \mathrm{cm}\end{array}$} & \multirow{2}{*}{$\begin{array}{l}\text { Total } \\
\text { soluble } \\
\text { solid } \\
\text { (TSS) \% }\end{array}$} & \multirow[t]{2}{*}{$\begin{array}{r}\mathrm{CaCO}_{3} \\
\mathrm{mg} / \mathrm{L}\end{array}$} & \multicolumn{4}{|c|}{ Cations } & \multicolumn{4}{|c|}{$\begin{array}{l}\text { Anions } \\
\text { Meg/L }\end{array}$} & \multicolumn{3}{|c|}{ Macro-nutrient } & \multicolumn{4}{|c|}{ Micro-nutrient } \\
\hline & & & & & $\mathrm{K}^{+}$ & $\mathrm{Na}^{+}$ & $\mathrm{Mg}^{++}$ & $\mathrm{Ca}^{+}$ & $\mathrm{SO}_{4}{ }^{\circ}$ & $\mathrm{Cl}^{-}$ & $\mathrm{HCO}_{3}{ }^{\circ}$ & $\mathrm{CO}_{3}{ }^{-}$ & $\mathrm{N}$ & $P$ & K & $\mathrm{Fe}$ & $\mathrm{Mn}$ & $\mathrm{Zn}$ & $\mathrm{Cu}$ \\
\hline Ismailia & 7.51 & 0.20 & 6.17 & 0.41 & 0.87 & 1.58 & 1.91 & 2.39 & 1.83 & 3.30 & 1.53 & 0.00 & 46.99 & 52.19 & 50.67 & 0.81 & 1.94 & 0.62 & 0.53 \\
\hline Suez & 7.89 & 5.43 & 173.68 & 21.18 & 0.72 & 26.47 & 5.55 & 14.8 & 19.39 & 26.98 & 1.13 & 0.00 & 42.94 & 13.37 & 356.20 & 3.77 & 4.47 & 2.76 & 1.31 \\
\hline Portsaid & 7.94 & 0.99 & 31.68 & 11.20 & 0.66 & 2.39 & 2.92 & 4.32 & 2.78 & 5.00 & 2.25 & 0.00 & 11.17 & 53.06 & 32.37 & 2.06 & 1.62 & 0.42 & 0.72 \\
\hline
\end{tabular}


Moreover the salts of cations and anions were highly significant among the districts, the highest significant domain salts of cation and anions were the chloride (Cl) $\left(F_{2,11}=6.35, T=22.81, P=0.02\right)$ and sodium $(\mathrm{Na})\left(F_{2,11}=5.97, T=24.04\right.$, $\mathrm{P}<0.02)$, in Suez (26.98 and $26.47 \mathrm{meq} \mathrm{L}^{-1}$ ) and Portsaid districts (5.00 and 2.39 meq $\mathrm{L}^{-1}$ ), respectively, whereas it was the lowest values in Ismailia district (3.30 and 1.58 meq L $^{-1}$ ), respectively (Table 6).

On other hand, the macronutrient (N.P.K.) refers to fertility status of the soil districts, nitrogen content was not significant difference effect $\left(F_{2,11}=0.64, T=38.43\right.$, $\mathrm{P}<0.55)$. While, there was little significant differences in phosphorus content $\left(F_{2}\right.$, $\left.{ }_{11}=4.41, T=43.59, \mathrm{P}<0.05\right)$ values in the studied three districts. Therefore, the potassium content $\left(F_{2,11}=60.76, T=104.89, P<0.0001\right)$ was highly significant greater level in Suez district (356.20 ppm) than obtained from Portsaid (11.18 ppm) and Ismailia $(0.40 \mathrm{ppm})$ districts, respectively.

However, micronutrient status revealed that there were significantly differences effects for iron $\left(F_{2,11}=5.36, T=2.63, P<0.03\right)$, magnesium $\left(F_{2,11}=8.60\right.$, $\mathrm{T}=3.65, \mathrm{P}<0.01)$, copper $\left(\mathrm{F}_{2,11}=4.35, \mathrm{~T}=0.91, \mathrm{P}<0.05\right)$ and $\mathrm{zinc}\left(\mathrm{F}_{2,11}=14.34\right.$, $\mathrm{T}=1.28, \mathrm{P}<0.00$ ) with estimated higher values in Suez (3.77-4.47-2.76-1.31), followed by Portsaid (2.06-1.62-0.42-0.72) and Ismailia districts (0.81-1.94-0.620.53 ), respectively (Table 6).

\subsubsection{Physical properties}

Data in Table 7 show that sand is dominant in all districts. However, the organic matter was not significant variations $\left(\mathrm{F}_{2,11}=0.92, \mathrm{~T}=0.31, \mathrm{P}<0.43\right)$. Organic matter percentage recorded $0.23 \%$ in Portsaid, followed descendingly by $0.21 \%$ in Ismailia and $0.18 \%$ in Suez districts.

Table 7. Physical contents of the studied soil samples in of Ismailia and Suez and Portsaid districts.

\begin{tabular}{|l|c|c|c|c|c|}
\hline \multirow{2}{*}{ District } & \multicolumn{3}{|c|}{ Particle size distribution \% } & \multirow{2}{*}{ Texture class } & $\begin{array}{c}\text { Organic } \\
\text { matter \% }\end{array}$ \\
\cline { 2 - 5 } & Sand & Silt & Clay & Sandy & 0.21 \\
\hline Ismailia & 57.00 & 18.00 & 25.00 & Sandy & 0.18 \\
\hline Suez & 68.68 & 20.72 & 10.60 & Sandy loam & 0.23 \\
\hline Portsaid & 50.00 & 17.40 & 32.60 & & \\
\hline
\end{tabular}

Results of statistical analysis showed that correlation coefficients values for chemical and physical soil properties were insignificantly correlated effects except for calcium carbonate and the element potassium $(k)$ that showed highly significant strong correlation. 


\section{Discussion}

The present work was yielded the presence of twenty-six fungal genera as Alternaria sp., Aspergillus bombycis, Aspergillus flavus, Aspergillus niger, Aspergillus oryzae, Aspergillus tamari, Beauveria bassiana, Cordyceps sp., Fusarium sp., Fusarium andiyazi, Fusarium begonia, Fusarium equiseta, Fusarium fujikuroi, Fusarium falciforme, Fusarium graminearum, Fusarium incarnatum, Fusarium lacertarum, Fusarium oxysporum, Fusarium solani, Helminthosporium sp., Lecanicillium lecanii, Metarhizium anisopliae, Paecilommyces fumosoroseus, Penicillium sp., Scytalidium sp., Trichoderma sp.; three bacterial species Bacillus aryabhattai, Bacillus megaterium, and Serratia odorifea; and only one species of nematode, Heterorhabditis sp.

The genera of Beauveria bassiana and Metarhizium anisopliae and Paecilomyces fumosoroseus were the specific entomopathogenic agents according to their pathogenicity values.

The distribution and occurrence of these insect pathogens varied in each of the three surveyed districts of Ismailia, Suez and Portsaid. This may have resulted in the variations of geographical characteristics of search areas, soil types and ecosystems. Higher frequencies occurred in Ismailia, followed by in Suez district. The lowest frequencies occurred in Portsaid district may be due to large variations of the edaphic factors in the studied districts.

It obvious that in this finding the means of species richness of Ismailia and Suez was higher than those of Portsaid. However, the Evenness index of the Ismailia and Portsaid was the lowest, in contrast, the index in Suez district was considerably high. Mean values of Shannon and Simpson indices were a very high in Suez and Portsaid compared to Ismailia. According to the results, the highest level of all diversity indices belongs to Ismailia and the least level could be found in Portsaid.

Shannon-Weiner index and Simpson Index were used to evaluate the species diversity. Shannon- Weiner Index assumes that individuals are randomly sampled from an independent large population and all the species are represented in the sample. Shannon diversity is very widely used index for comparing diversity between various habitats. It was calculated in order to know the species diversity in different habitat based on the abundance of the species. Evenness is a measure of the relative abundance of different species making up the richness of an area. This evenness is an important component of diversity indices and expresses evenly distribution of the individuals among different species (Leinster and Cobbold, 2012).

Simpson Index (D): It measures the probability that two individuals randomly selected from a sample will belong to the same species. Simpson gave the probability 
of any two individuals drawn from noticeably large community belonging to different species. The presence of one individual of a species is not necessarily indicative of the species being present in a large number. The value of Shannon Weiner Diversity Index usually falls between 1.5 and 3.5, only rarely it surpasses 4.5 . A value near 4.6 would indicate that the numbers of individuals are evenly distributed in all the species. Therefore, diversity indices provide important information about rarity and commonness of species in a community. Potential use of these diversity indices might be sensitive to any changes in the species data that may occur at any district.

The distribution of bacterial species and the entomopathogenic nematode were lower than the fungal species. This may be due to their the ability to survive in different types of soil, high and low salinity, percentage of calcium carbonate, different salts levels of cations and anions, macro and micro nutrients. There no evidence was found to be confirmed or deny the relation between the occurrence of the bioagents and physical or chemical composition of soil. However, soil pH and altitude had minor or no effect on distribution.

Our results were compatible with that obtained by (Vanninen, 1996; Meyling and Eilenberg, 2007; Sun and Liu, 2008; Eladawy et al., 2012; Sayed and Abolmaaty 2013). Vanninen (1996) revealed that soil type did not affect the occurrence of any of the microbial species in Finland. In contrast, other studies by Herrera et al., 2008 indicated that habitat type might influence entomopathogenic nematodes occurrence. Moreover, clay, P2O5, Zn, $\mathrm{Cu}$ and hexachlorobenzene contents negatively correlating with nematodes population density. Quesada-Moraga et al., 2007 showed that $\mathrm{pH}$ and clay content were predictive variables for the occurrence of $B$. bassiana, whereas organic matter content was the predictive variable for $M$. anisopliae.

The present work is greatly important because it document the occurrence of entomopathogenic agents in various habitats and localities and also yield of new species and isolates of the bioagents. The occurrence and distribution of the native entomopathogens may be through a light on the secret role of these bioagents in soil against certain economic pests that spend one or more stage of their life cycle. Accordingly, the new isolates will be evaluated in the future for their control potentials against natural hosts under local conditions.

In general, our findings are early steps toward using of these bioagents for pest control. It is clear that more research work is needed to carry out numerous steps towards preservation our hidden treasure of entomopathogenic agents in soil and avoid ill factors that may affect their occurrence, distribution and diversity to play an effective role in pest control. 


\section{REFERENCES}

1. EL-Adawy, A.M.; A, M.M. Sayed and H. A. AbdelGwad. 2012. Anagasta kueinella as an Isolation Bait of Entomopathogenic Agents. Egypt. J. Agric. Res., 90(2):601-606.

2. El-Adawy, A. M.; E. S. El-barogy; M. H. S. Naeim; M. A. A. Essa; M. H. El-hamawi and T. A. Sharkawy. 2001. Factors affecting the natural occurrence of some insect biocontrol agents in cultivated soil in Ismailia governorate. Egypt. J. Agric. Res., 79(2):419-430.

3. Gee, G.W. and J.W. Bauder. 1986. Particle-size analysis. p. 383-411. In A. Klute (ed.) Methods of soil analysis. Part 1. $2^{\text {nd }}$ ed. Agron. Monogr: 9, ASA and SSSA, Madison, WI.

4. Glare, T. R.; Roma, L. Gwynn and Maria, E. Moran-Diez. 2016. Development of Biopesticides and Future Opportunities. In Travis R. Glare and Maria E. MoranDiez (eds.), Microbial-Based Biopesticides: Methods and Protocols, Methods in Molecular Biology, vol. 1477, DOI 10.1007/978-1-4939-6367-6_16, (C) Springer Science+Business Media New York 2016.

5. Herrera, R. C.; J.M. mez-Ros; M. Escuer; L. Cuadra; L. Barrios and C. Gutierrez. 2008. Diversity, occurrence, and life characteristics of natural entomopathogenic nematode populations from La Rioja (Northern Spain) under different agricultural management and their relationships with soil factors. Soil Biol \& Biochem, 40: 1474-1484.

6. Jackson, M . L. 1967. Soil chemical analysis. Prentice Hall of India Private Limited, New Delhi.

7. Kaya, H.K., and S. P. Stock (1997). Techniques in insect nematology. In L. A. Lacey, ed. Manual of Techniques in Insect Pathology. San Diego, CA: Academic Press. pp. 281-324.

8. Kaya, H. K., and R. Gaugler. 1993. Entomopathogenic nematodes. Ann Rev. Entomol, 38: 181-206.

9. Leinster, T. and C. A. Cobbold. 2012. Measuring diversity: the importance of species similarity. Ecol, 93(3): 477-489.

10. Logan , N . A . and P, De Vos. 2009. Genus Bacillus Cohn 1872. In Bergey's Manual of Systematic Bacteriology, $2^{\text {nd }}$ ed., vol: 3, New York.

11. Magurran, A. 2004. Measuring Biological Diversity. Black well Publishing ,Oxford. p. 256. 
12. Meyling, N. V. and J. Eilenberg. 2007. Ecology of the entomopath-ogenic fungi Beauveria bassiana and Metarhizium anisopliae in temperate agroecosystems: potential for conservation biological control. Biological Control, 43:145-155.

13. Promputtha, I.; R. Jeewon; S. Lumyong; E. H. C. McKenzie and K. D. Hyde. 2005. Ribosomal DNA fingerprinting in the identification of non sporulating endophytes from Magnolia liliifera (Magnoliaceae). Fungal Diversity, 20: 167-186.

14. Quesada-Moraga, E.; J. A. Navas-Cortes; E.A.A. Maranhao; A. Ortiz-Urquiza and C. Santiago-Alvarez. 2007. Factors affecting the occurrence and distribution of entomopathogenic fungi in natural and cultivated soils. Mycol. Res., 111: 947966.

15. Ravensberg, W. J. 2011. Implementation of a microbial pest control product in an integrated pest management programme. In: A Roadmap to the Successful Development and Commercialization of Microbial Pest Control Products for Control of Arthropods. Progress in Biological Control 10, Springer, Dordrecht, pp. 235-293.

16. Sayed A. M.M. and S. M. Abolmaaty. 2013. Geographic information system used for assessing the naturally occurrence and biodiversity of entomopathogens in Egypt. Egyptian J. Biol. Pest Control, 23 (1): 159 -168.

17. Sun, B. D . and X.Z . Liu. 2008. Occurrence and Diversity of Insectassociated Fungi in Natural Soils in China. App. Soil Ecol., 39: 100-108.

18. Vanninen, I. 1996. Distribution and occurrence of four entomopathogenic fungi in Finland: effect of geographical location, habitat type and soil type. Mycol. Res. 100, 93-101.

19. Vega, F. E.; M. S. Goettel; M. Blackwell; D. Chandler; M. A. Jackson; S. Keller; M. Koike; N. K. Maniania; A. Monzón; B. H. Ownley; J. K. Pell; D. E. N. Rangel, and H. E. Roy. 2009. Fungal entomopathogens: new insights on their ecology. Fungal Ecol., 2:149-159.

20. Woodring, J. L. and H. K. Kaya. 1988. Steinernematid and Heterorhabditid nematodes: A handbook of techniques. Southern Cooperative Series Bulletin 331.30 pp. Arkansas Agricultural Experiment Station, Fayetteville. 


\title{
التنوع الحيوي وتواجد المسبيات الممرضة للحشرات بقطاع قناة السويس
}

\author{
عاطف محمود محمد سيد' ، سيد على احمد ابر اهيمَ ، عبداله محمد مرسى العدوى'
}

\section{1 - معهر بحوث وقاية النباتات ، مركز البحوث الزراعبة ، جيزه ، مصر r- كلية العلوم الزراعية البيئية بالعريش - جامعة العريش}

تم در اسة تو اجد و انتشار المسببات الممرضة للحشر ات فى عينات التربة التى تم جمعها من ثلاث مجافظات (الاسماعيلية و السويس وبورسعيد) تمثل قطاع قناة السويس ، بجمهورية مصر العربية مع استخدام نظم المعلومات الجغر افية فى تحديد اماكن اخذ عينات التربة. وبإستخدام حشرة

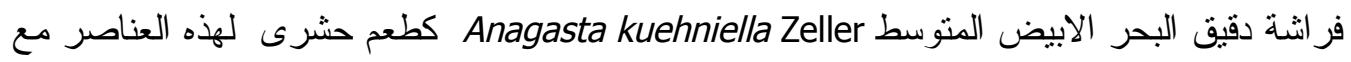
در اسة العو امل المؤثرة علي تو اجدها و انتشار ها.

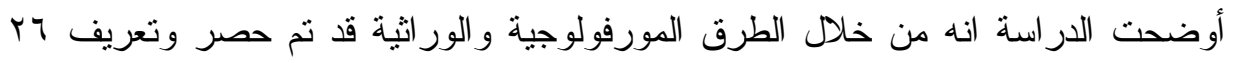

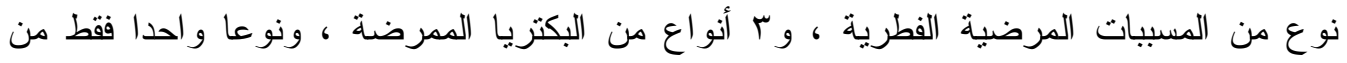
النيماتودا المتطفلة علي الحشرات .

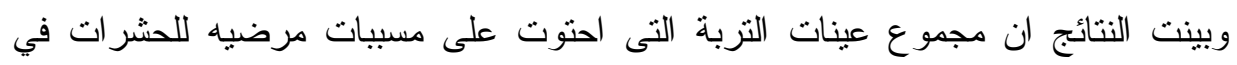

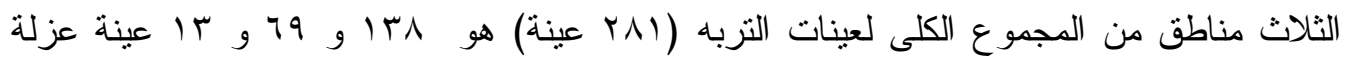

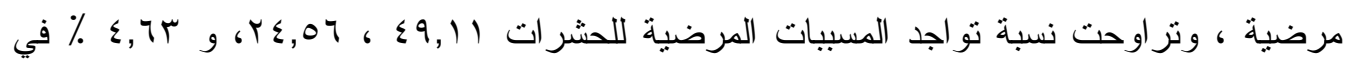
محافظات الإسماعيلية والسويس وبورسعيد على التوالي. وقد أظهر التحليل الإحصائي ان نواجد أند و انتشار المسببات المرضيه للحشرات تختلف اختلافا معنويا بدرجة عالية بين المناطق التي شملتها الدراسة وكذلك بين المسببات المرضية. حيث كان الاكثر نكرارا في منطقة الإسماعيلية بنسبة

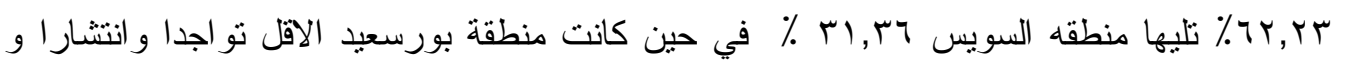

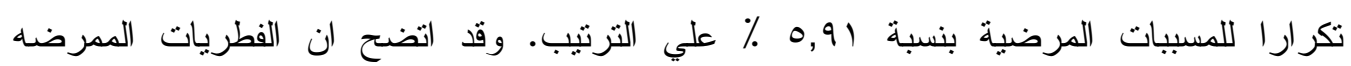

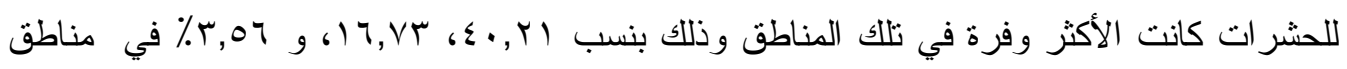

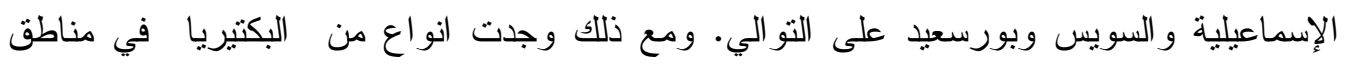

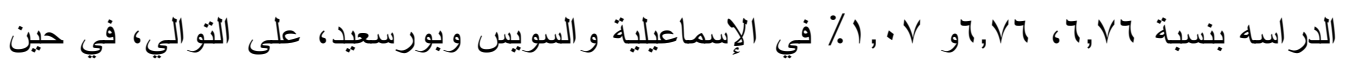

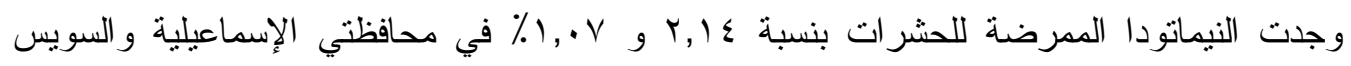

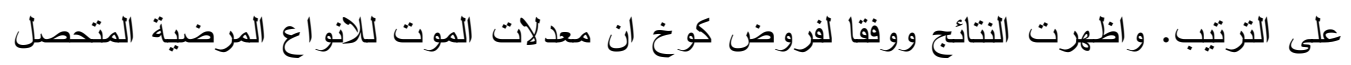
عليها قيد الدر اسة ضد يرقات A. kuehniella في المحافظات الثناث كانت عالية المعنوية. وتر اوحت

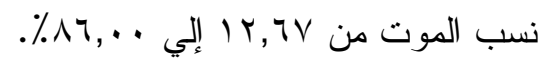


Beauveria bassiana, Metarhizium anasopliae, وتعتبر الانواع

Paecilomyces fumosoroseus and Lecanicillium lecanaii

تخصصا .

تعتبر مؤشرات التتوع البيولوجى ذات اهية عن ندرة و انتشار الانواع بمنطقة ما ـ وقد تم

قياس دلائل التنوع الحيوي Diversity indices المختلفة منل دليل الغني و والتكافؤ و التتوع Richness index, Diversity index and Evenness index . أوضح نتائج التحليل الاحصائي انه يوجد فروق معنوية لمؤشرات التتوع الحيوي في المحافظات الثنلاث ـ كذالك أظهرت النتائج ان الانواع التي نم تسجيلها في محافظة الاسماعيلية هي الاكثر تتوعا عن تللك الموجودة

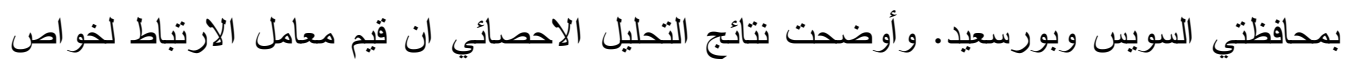
التربة الكيمائية و الفيزيائية ليس لها ارتباط معنوي بانتشار المسببات المرضية فيما عدا نسبة كربونات الكالسيوم ومحتوي الفوسفور بالتربة ـ ونسنتتح من النتائج ان خواص التربة الكيمائية

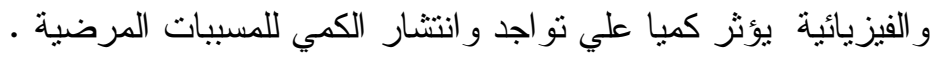

